\title{
DISSOLUTION OF VESICAL CALCULI WITH RENACIDIN IN A PARAPLEGIC MAN
}

\author{
By JefFrey R. Woodside, M.D. and E. David Crawford, M.D. \\ Division of Urology, University of New Mexico School of Medicine, 221 I Lomas Blvd., N.E., \\ Albuquerque, New Mexico, 87I3I, U.S.A.
}

\begin{abstract}
Vesical calculi are common in spinal cord injury patients. The majority are composed of magnesium ammonium phosphate, a compound readily soluble in the solvent Renacidin. We describe a paraplegic man with recurrent bladder stones in whom cystolitholopaxy was unsuccessful. His calculi were completely dissolved by continuous Renacidin bladder irrigation. We recommend Renacidin for the initial treatment of vesical calculi in selected spinal cord injury patients. Many such stones will completely dissolve and others may be made softer or smaller, facilitating cystolitholopaxy. A significant number of patients will be spared the inconvenience, cost and morbidity of hospitalisation for a surgical procedure.
\end{abstract}

\section{Introduction}

HisTORICALLY, bladder calculi have represented a formidable cause of morbidity and mortality in spinal cord injury patients. Thirty per cent of paraplegics in World War II with complete spinal cord transsection developed this complication. During the past Io years, early institution of intermittent catheterisation, external sphincterotomy and pharmacological management have rendered the great majority of these patients catheter-free, resulting in a decreased incidence of vesical calculi. However, this complication does occur, and may result in multiple surgical procedures and significant morbidity. Renacidin ${ }^{\star}$ was introduced as a solvent for urinary calculi by Mulvaney (1959). The fact that it can be a very effective primary agent for dissolving bladder stones is not widely appreciated. We herein describe a patient with recurrent bladder calculi in whom attempted cystolitholopaxy (cystoscopic crushing) was unsuccessful and whose calculi were completely dissolved with Renacidin bladder irrigations, thereby avoiding cystolithotomy.

\section{Case Report}

A 24-year-old male with an established partial TI2 spinal cord injury was admitted for intensive treatment of ischial decubitus ulcers. Four years earlier, he had a cystolithotomy for a magnesium ammonium phosphate calculus. He had partial sensory preservation of both rectal and bladder fullness, balanced bladder function and wore a condom catheter. Routine urine culture revealed more than Io0 000 colonies per millilitre Proteus mirabilis. An abdominal roentgenogram showed no vesical or renal calcifications. Intravenous pyelogram demonstrated normal kidneys and ureters, with a moderately trabeculated bladder. There was no evidence of vesico-ureteral reflux during voiding cystography. To eliminate non-radio-opaque bladder stones as the source of his bacteruria, cystoscopy was performed and two IO-I $2 \mathrm{ml}$ flat, soft-appearing calculi were found.

Cystolitholopaxy was attempted under general anesthesia. However, a persistent

* Guardian Chemical Corp., Hauppauge, New York, U.S.A., II 787. 
reflex erection prevented successful insertion of the lithotrite. Pharmacologic manipulation with atropine, ketamine hydrochloride and inhalation amyl nitrite were unrewarding and the procedure was terminated. Continuous bladder irrigation with Io per cent Renacidin solution at $50 \mathrm{ml}$ per hour was instituted and appropriate antibiotics were administered. Cystoscopy was repeated on the 8th day of irrigation, and complete dissolution of the calculi was noted. A subsequent urine culture was sterile. He was discharged on weekly Renacidin instillations to prevent recurrence.

\section{Discussion}

Renacidin consists of a mixture of the lactones, anhydrides, and magnesium salts of multivalent organic acids from the gluconic and citric group (Ries \& Malamet, I962). The Io per cent solution used for irrigation has a pH of 3.9. The mode of action is postulated to be a magnesium-calcium ion exchange in the calculus, whereby insoluble calcium salts are exchanged for soluble magnesium salts (Blaivas, Pais \& Spellman, I975; Jacobs \& Gittes, 1976). Calculi composed of calcium carbonate, calcium phosphate and magnesium ammonium phosphate are known to be effectively dissolved; however, those composed of uric acid, urates and oxalate are insoluble (Abeshouse, Abeshouse \& Doroshow, 196I).

In addition to its use in vesical calculi, Renacidin has been utilised in the treatment of renal stones. Numerous investigators report the effectiveness of Renacidin irrigations through nephrostomy tubes in order to dissolve residual postoperative stone fragments, or through ureteral catheters to primarily dissolve renal calculi (Mulvaney, I960; Mulvaney \& Henning, 1962; Ries \& Malament, 1962; Fam, Rossier, Yalla \& Berg, 1976). Several deaths occurring during renal Renacidin irrigation resulted in the United States Food and Drug Administration withdrawing approval for its use in the renal pelvis. These deaths and most reported complications can be attributed to sepsis occurring with irrigation of an obstructed kidney, rather than to Renacidin itself. It has been administered intravenously to rabbits and dogs and has not resulted in serious toxicity (Ries \& Malament, 1962; Nemoy \& Stamey, 1976). Recent reports demonstrate both its safety and efficacy, including its use in spinal cord injury patients (Fam, Rossier, Yalla \& Berg, 1976) when sterility of the urine is maintained and the technique insures immediate cessation of irrigation when evidence of obstruction, back pain or fever occur (Blaivas, Pais \& Spellman, I975; Jacobs \& Gittes, 1976).

Mulvaney (I960) is credited with the initial use of Renacidin in the treatment of bladder calculi. Several paraplegic patients used the solution and completely dissolved their stones. Abeshouse (I96I) described complete dissolution of bladder stones in two of seven patients treated with Renacidin irrigation. Cystolitholopaxy was facilitated in the remaining five as a result of decreased size or change in stone composition. An intractable intra-operative reflex erection in our patient made cystolitholopaxy impossible; therefore, treatment with continuous Renacidin bladder irrigation was instituted with gratifying results.

\section{Conclusions}

Vesical calculi are common in spinal cord injury patients and may require multiple surgical procedures. The majority of these stones are composed of magnesium ammonium phosphate, which is readily soluble in Renacidin. Stone 
dissolution may be accomplished by continuous irrigation of the solution. Alternatively, $60 \mathrm{ml}$ may be instilled three to four times per day and retained for 30$45 \mathrm{~min}$. If the stones fail to dissolve, they frequently will decrease in size and become soft, thus facilitating cystolitholopaxy. Appropriate antibiotics should be given during treatment. Since many spinal cord injury patients are skilled at intermittent catheterisation, they may treat themselves as outpatients and avoid hospitalisation. We encourage others to attempt to dissolve bladder stones in these patients with Renacidin before resorting to surgery.

\section{RÉSUMÉ}

Des cystolithes sont fréquents chez les malades qui souffrent d'une lésion de la moelle épinière. La plupart en sont composés d'un phosphate de magnésium ammonium, un composé qui se dissout facilement dans le dissolvant urinaire Renacidin. Nous décrivons un homme atteint de la paraplégie qui a eu, à plusiers reprises, des cystolithes et chez qui la cystolitholopaxie est restée sans succès. Ses calculs s'étaient complètement dissous grâce à l'irrigation vésiculaire ininterrompue avec Renacidin. Nous recommandons du Renacidin pour le traitement initial de la plupart des cystolithes chez des malades qui souffrent d'une lésion de la moelle épinière. Beaucoup de ses calculs se dissoudront complètement, et d'autres pourraient être rendus plus mous ou plus petits, ce qui facilitera une cystolitholopaxie. Les inconvéniences, les frais et le côté morbide d'une séjour à l'hôpital, qu'exige un procédé chirurgical, seront épargnés à bon nombre de malades.

\section{ZUSAMMENFASSUNG}

Blasensteine kommen häufig bei Patienten vor, die eine Rückenmark-Verletzung haben. Die meisten bestehen aus Magnesium Ammonium Phosphat, eine Verbindung, die im Harn-Auflösungsmittel Renacidin sofort löslich ist. Wir beschreiben einen Querschnittgelähmten, der öfters Blasensteine gehabt hat und bei welchem die Zystolitholopaxie ohne Erfolg geblieben ist. Seine Steine haben sich, dank einer ununterbrochenen BlasenIrrigation mit Renacidin, gänzlich aufgelöst. Wir empfehlen Renacidin für die InitialBehandlung der meisten Blasensteine bei Patienten mit Rückenmark-Verletzungen. Viele solcher Steine werden sich gänzlich auflösen und andere können damit weicher oder kleiner gemacht werden, was eine Zystolitholopaxie erleichtert. Einer bedeutsamen Anzahl von Patienten werden somit die Unannehmlichkeiten, die Kosten und die Indisposition, verbunden mit dem Krankenhausaufenthalt, den eine chirurgische Operation erfordert, erspart bleiben.

\section{REFERENCES}

Abeshouse, G., Abeshouse, B. S. \& Doroshow, L. W. (I96I). The use of Renacidin as a solvent for vesical calculi : preliminary report. F. Urol., 86, 69.

Blaivas, J. G., Pais, V. M. \& Spellman, R. M. (I975). Chemolysis of residual stone fragments after extensive surgery for staghorn calculi. Urology, 6, 680.

Fam, B., Rossier, A. B., Yalla, S. \& BERG, S. (1976). The role of Hemiacidrin in the management of renal stones in spinal cord injury patients. F. Urol., II6, 696.

GuttmanN, Sir Ludwig (1976.) Spinal Cord Injuries. Comprehensive Management and Research, 2nd Edition. Blackwell, Oxford.

JACOBS, S. C. \& GiTTES, R. F. (I976). Dissolution of residual renal calculi with Hemiacidrin. F. Urol., $115,2$.

MULVANEY, W. P. (I959). A new solvent for certain urinary calculi: a preliminary report. F. Urol., 82, 546.

MulvaneY, W. P. (I960). The clinical use of Renacidin in urinary calcifications. F. Urol., 84, 206.

Mulvaney, W. P. \& Henning, D. C. (1962). Solvent treatment of urinary calculi: refinements in technique. $\mathcal{F}$. Urol., 88, 145 .

Nemoy, N. J. \& Stamey, T. A. (1976). Use of Hemiacidrin in management of infection stones. F. Urol., 116, 693 .

Ries, S. W. and Malament, M. (1962). Renacidin: a urinary calculi solvent. F. Urol., 87,657 . 